\title{
Causes and Solutions of Poverty in Lesotho
}

\author{
Moeketsi Kali
}

Pan African University Institute of Governance, Humanities and Social Sciences, University of Yaoundé II, Cameroon

\section{ARTICLE INFO}

\section{Keywords:}

Poverty

Millennium Development Goals Sustainable Development Goals Agenda 2063

Lesotho

\begin{abstract}
Sub-Saharan Africa is a home of the world's poorest countries. After more than half a century since independence, Lesotho remains in the list of the poor countries in Sub-Saharan Africa despite the adoption of the Millennium Development Goals, Sustainable Development Goals, and Agenda 2063. The aim of this paper is to examine the causes of poverty in the country together with the solutions taken to combat it. The paper asks the following questions: What are the main causes of poverty in Lesotho? What solutions has the government put in place to reduce it? The paper anchors on content analysis to provide answers to these questions. It argues that poverty and its ills remain pervasive in Lesotho because of the government's poor policies and failure to create job opportunities. The paper shows that the government of Lesotho has closed gender disparity in terms of educational attainment and health and survival. It has also developed a robust social protection system to reduce poverty among the elderly population, people living with disabilities, children, and women in the country. Despite this success, the government has reversed the gains made since 2006 in terms of political empowerment and economic participation and opportunities. Notwithstanding, the SDGs and Agenda 2063 provides a room for the government to reduce poverty in the country by making good on its promises entailed in the two international instruments.
\end{abstract}

\section{Introduction}

For many decades, Lesotho has not succeeded to delete itself from the list of the poorest countries in the world (Wilson, Mapetla \& Power-Drutis, 2008). May, Roberts, Moqasa and Woolard (2002) established that the depth and severity of poverty in the county worsened long in 1986/7 and at least $34.7 \%$ of Basotho were classified as very poor or ultra-poor and even in 1994 the status quo did not change significantly. In addition, after a decade, Ueckermann and Blignaut (2005) noted that Lesotho's poverty was dire than that of many countries. Equally, Ventura (2020) observed that the country is still poor and ranks it number 36 among the poorest countries of the world.

Since the 1970s, the country overburdened itself with external debt. According to the Global Economy.com (2020), its average debt value since 1970 to 2018 was $30.84 \%$ with a commendable minimum of $4.24 \%$ in 1974 and a bad record of $68.08 \%$ in 2000. Around 2018, the external debt reached $29.22 \%$ and during the same period, the world average of 117 countries' debt was $51.42 \%$. Although borrowing may not always be bad for a country, it is certainly debilitating for a country with bad governance because the debt will only serve to aggravate poverty. Often than not, debt service does not help reduce poverty because it causes

\footnotetext{
* Corresponding author E-mail address: kalimoeketsi@gmail.com 
some distortions in an economy and discourages investment as well as economic growth (Senadza et al., 2018).

Despite its constant borrowing, Lesotho cannot afford to create enough employment opportunities for its citizens. Although the country is small and occupies only 30,355 square kilometres, unemployment, income inequality and poverty are pervasive (Damane \& Sekantsi, 2018; United Nations Development Programme, 2020; Wilson, Mapetla \& Power-Drutis, 2008). There is either a problem with the policies adopted by the country or the way policies are implemented. If the challenge is at the policy level, the country can easily solve that by learning from South Africa, its neighbour.

Lesotho is landlocked by South Africa, one of the top giant African economies. The success of its neighbour provides an opportunity for Lesotho to develop yet the success of South Africa is not trickling down to its poor neighbour (Delport, 2020). Instead of concentrating on developmental issues, South Africa is expending its energy to help Lesotho to solve its political crises. It intervened in a turmoil that led to the Southern African Development Community to intervene in 1998, an attempted coup that forced former Prime Minister Thabane to flee to South Africa in 2014, and the recent tension that compelled him to resign in 2020 (Kali, 2019, Mohloboli, 2020). This means that the country is not concentrating enough energy on poverty reduction but political instability. It is important for the country to focus its policies toward poverty reduction.

To design effective policies that reduce poverty, it is very important to understand its causes. Generalizing the causes of poverty and adopting general solutions cannot effectively solve the perceived problems. Every problem is unique and requires special solutions. Causes of poverty differ because of political, geographic and social context. Some studies associate poverty in Lesotho with the size of families, living in rural areas, women-headed households, households with older heads, and heads that are unemployed and look after the home (May \& Roberts, 2001; Omole, 2003). This literature can hardly distinguish between the causes and consequences of poverty.

\section{Methodology}

The purpose of this paper is to examine the causes of poverty and solutions taken to combat it in Lesotho. The paper poses the following questions: What are the main causes of poverty in Lesotho? What solutions has the government put in place to reduce poverty? To answer these questions, the paper examines the literature in the form of journals, books, reports, internet sources, and newspapers and employs content analysis to assess the explanations put forward to explain why Lesotho is poor. The paper views poverty from the monetary approach, social exclusion approach, participatory approach, and the capabilities approach. The analysis excludes natural and external sources of poverty such as disasters, geographic factors, and colonialism. The objective of this paper is to explore the causes of poverty in Lesotho and assess the solutions taken by the government to reduce poverty in the country. The first part of this study is an introduction followed by a methodology section and a literature review. The subsequent parts present the finding and discussions on the causes of poverty and strategies put in place to combat it. The last part of the paper presents the conclusion.

\section{Literature review}

\subsection{Conceptualization of Poverty}

To have a clear picture of poverty, it is necessary to examine it as a multidimensional phenomenon and capture the actors around it. It is important to assess the social, economic and political context of a specific country and examine the practices of different institutions of the state that either tries to reduce or aggravate poverty. Khan (2001) observed that the scourge of poverty cuts across ethnic lines, gender, location, age, and income sources. In most cases, 
women, children, and people with disabilities suffer more than other groups. Minority groups, depending on the political context, usually suffer the most. These religious, cultural, indigenous, or gender-based groups.

Deprivation or poverty can be viewed in relation to material possession, social, cultural, and political aspects of life. Other definitions of poverty emphasize on the resources or space of utility and this view is usually adopted when using the different versions of the monetary approach. The monetary approach entails economic growth and resource approaches (Dini \& Lippit, 2009). Where it is defined in terms of capabilities, the emphasis touches on the freedom to live a life valued by an individual. Some definitions try to be universal and call for the use of universal indicators. The monetary and social exclusion approaches were initially designed for developed countries hence each approach encounters problems when translated or applied to the developing countries (Laderchi, Saith \& Stewart, 2003). For instance, the monetary approach takes for granted the value of the subsistence production although African countries rely more on it than monetary transactions (May, Roberts, Moqasa \& Woolard, 2002). The problem with a social exclusion approach is experienced when it comes to the diversity of cultures and substantial differences in the norms of societies that define what constitutes the social exclusion (Laderchi, Saith \& Stewart, 2003).

Poverty is a multi-layered, multi-dimensional, and dynamic phenomenon rooted largely in certain groups in society (Khan, 2001; Dini, 2009). It mainly affects certain gender, an ethnic group that is sidelined by a ruling ethnic class, and marginalized groups such as people living with disabilities. When a country is poorly governed, such groups usually have a hard time finding jobs, securing governments contracts, and business licenses due to practices that favour ethnic affiliations and political party affiliations (Bratton \& van de Walle, 1994). The inability of certain social groups to take part in designing policies, participating in their implementation, securing jobs, and being treated equally like others aggravate poverty. This implies that the definition of poverty is not limited to factors such as one's income but covers social and political factors too.

Poverty can also be viewed from a participatory approach. This approach is the same as social exclusion and capability approaches. It contends that poverty is a multifaceted condition that has to do with the organization and structure of power (Dini, 2009). This approach considers the exclusion of an individual from society as a source for chronic poverty but mainly focuses on the issues such as not allowing the poor to participate in policy design, implementation and monitoring as the principal causes of poverty (Dini, 2009). The participatory approach advocates for a breakdown of the dominant political structure that serves to exacerbate poverty so that the system that would be put in place can value local knowledge and perspectives of the poor (World Bank, 2006).

The participatory approach recognizes that poverty is aggravated by elites who ignore local knowledge and adopt a top-down approach to policy-making and pay no attention to the power of the bottom-up approach (Annamalai et al., 2016). Poverty cannot be reduced when the locals and the poor have no room to share their knowledge and recommend necessary social action policy for their problems. Continuous exclusion leads to social passivism and eventually the poor end up believing that they cannot extricate themselves from poverty because their situation is natural. They believe there is absolutely nothing they can do to change their predicament.

Sen (1983) associates the definition of poverty with human entitlements. These are the various bundles of commodities, goods, and services that one has access, command, and control over. The means by which those entitlements are acquired is usually considered when defining poverty (Adeyeye \& Ajakaiye, 2002). The entitlements also extend to the availability of the needed goods such as electricity, house rent, water, food, money, and clothes (Townsend, 1962). Other scholars simply view poverty from a broader perspective and argue that it refers 
to the state or condition in which an individual is unable to meet basic needs such as food, clothing, shelter, education, and healthcare (Adeyeye \& Ajakaiye, 2002; World Bank, 1996). Poverty refers to the social differences between individuals with respect to possession. In this paper, we adopt the definition of poverty proposed by Gupta (1984) which argues that poverty is the state of having little or no goods, income, or other means of support. Poverty occurs when some people in a country or society are unable to achieve a level of material well-being that constitute a minimum standard in society (Ravillion, 1992). Universally, the material possessions deemed necessary for survival are food, water, shelter, and clothes. However, in Lesotho, it is common to hear someone say the other is poor because they do not have decent shoes or clothes, or lives in an old house, or owns a very old car. Over these, there are still things like clothes or luxurious vehicles an ordinary person would be ashamed to appear in public without (Sen, 1983). So the definition of poverty is context-specific and has to take into consideration the culture and attitudes of a specific society. The different social and political contexts have different and specific causes of poverty.

Poverty is also defined in terms of income. In this sense, it refers to a situation where an individual does not have enough money to satisfy his/her basic needs simply because such a person is either unemployed or underemployed (Baylis et al., 2011). Absolute poverty lines are often based on a measurement of the minimal consumption of needs and the number of goods needed to fulfil those needs (Ravallion, 1992). For instance, the World Bank considers people to be poor if they are living on less than $\$ 1.90$ (US dollar) per day (Naidoo, 2019).

Scholars distinguish between absolute and relative poverty. When the former is used, it shows a set of fixed levels that remain the same over time. When a relative approach to poverty is utilized, a varying level of what a household is supposed to have in order to meet their basic needs is set, and those who fall below that threshold are counted among the poor (May, et al., 2002). Townsend (1985) argues that absolute poverty methods, as opposed to relative poverty, mistakenly give weight to physiological needs over social needs. However, relative poverty put weight on a person's ability to meet social expectations, obligations and customs (Townsend, 1993).

Economic deprivation is largely used to define what constitutes a definition of poverty mainly because it is relatively simpler for policy-makers and scholars to operationalize (Beard, 1999). It is based on the notion that a household should consume a certain minimal level of goods per day to survive and maintain its livelihood. To measure economic deprivation, a conventional measure in line with absolute poverty line is applied and this requires the selection of a fixed level of consumption that remains the same in spite of an individual's life context hence the establishment of $\$ 1.90$ per day (Ravallion, 1992). However, Chambers (1995) rejects the primacy of economic deprivation and the minimalist view of poverty by arguing that consumption and income should both be considered in the examination of poverty. Chamber's criticism calls for a multi-faceted approach to deprivation. It demonstrates that poverty is an encompassing phenomenon and requires an evaluation of the circumstances surrounding a poor household or an individual. This broader approach helps us to examine the various causes of poverty and to understand the solutions thereof. Hence, this study adopts the basic needs and income approach to explaining poverty (Streeten, 1979; Wong, 2012). The former regards poverty as the lack of adequate material possessions while the latter highlights the need to have a certain level of income necessary to meet one's needs. The paper's emphasis is placed on the absolute poverty which refers to the condition where a household's income is below $\$ 1.90$ per day and therefore is unable to meet an individual or family's basic needs which include shelter, food, and housing.

Although conceptions of poverty differ, most of them underscore the necessity for food, clean water, sanitation, and shelter. When the absolute poverty approach is employed, there are reasons to believe that Lesotho is one of the world's poorest countries. Based on the World 
Bank (2019), the Sub-Saharan African population is economically deprived than other places. Following this premise, this paper examines how a poor Sub-Saharan African country attempts to tackle and combat poverty based on international strategies.

According to the World Bank (1996), poverty has to be understood as the lack of basic needs such as food, health care, education, and shelter which are required for a meaningful life. The World Bank (1996) also considers poverty in terms of income. The changes in average income contribute to one's status so that when his or her income falls below the set threshold he or she is regarded as poor and vice versa. When monetary terms are used to define poverty, a certain group of people in society who are not capable of purchasing any specified item that is referred to as basic will consequently be deemed poor.

The World Bank suggests indicators of poverty. It revised the international poverty line in 2015 that was set at $\$ 1$ per day to $\$ 1.90$ per day (Roser and Ortiz-Ospina, 2019). This measurement is solely based on the monetary value of an individual's daily consumption. The advantage of this method of measurement is that the dollar is easily convertible to various currencies. Equally, the purchasing power parity can be adjusted to address the challenges encountered when measuring poverty (Roser and Ortiz-Ospina, 2019). However, Roser and Ortiz-Ospina (2019) claim that the determinant measure is extremely low. This would mean that anyone whose living condition is below $\$ 1.90$ per day should be regarded as extremely poor. There may be problems related to measuring poverty, especially in Lesotho where people depend more on farming than income from other walks of life for their daily survival (Wason \& Hall, 2004). Notwithstanding, it is out of the ambit of this study to examine the challenges of measuring poverty. This study adopts, for analytical purpose, the approach of the World Bank of describing poverty as living under $\$ 1.90$ per day. The World Bank asserts that out of the world's 28 poorest countries, 27 are found in Sub-Saharan Africa (Patel, 2018), and Lesotho happens to be one of the continent's poorest countries (World Population Review, 2020).

\subsection{General Causes of Poverty and Solutions}

Among the numeral causes of poverty citied in the literature, the following stand out:

- Political instability and civil strive

- Corrupt politicians together with the rent-seeking bureaucrats

- Systematic discrimination and exclusion of some groups based on gender, age, race, ethnicity, political affiliation, or religion

- Policies that make access and control of land difficult for certain groups such as women and the youth

- Unfair and ill-defined property laws or the poor enforcement of the laws in place, especially those pertaining to agriculture and use of natural resources

- Economic policies excluding and discriminating against women, youth, and marginalized groups in their development processes (Khan, 2001; Kali, 2018; Kali, 2020a).

The World Bank (1996) assessed the scope and nature of poverty in Sub-Saharan Africa and came out with the following causes:

- Inadequate access to employment

- Inadequacy of physical assets and minimal access to financial assets by the poor

- Low access to the means which support rural agriculture in regions that are regarded as poor

- Poor access to markets by the poor who have goods and services to trade.

- The human capital not well endowed due to inadequate access to education and other facilities

- The failure to protect natural resource endowments from destruction 
- The inability to access assistance by victims of transitory poverty due to natural disasters and wars

- The inadequate participation of the citizens in designing development programs.

The causes of poverty are multifaceted hence the solutions to it must take a multidimensional approach. Its causes are traceable to economic, social, and political conditions of life. The nature of a political system, the economy of a country, and socio-cultural aspects should be taken into consideration when a government designs policy that seek to combat poverty. Any government that makes an effort to improve health care system, education sector, political climate, traditional practices, and create employment opportunities is contributing to poverty reduction strategies and efforts (Stapleford, 1919).

For poverty to be reduced, economic growth must take place. When the economy is not growing and jobs are not being created, the persistent levels of poverty among a substantial portion of the population can stifle the possibility of economic development (Khan, 2001). Also, when the distribution of wealth and income are unequal and favour a small segment of the population at the expense and exclusion of a larger population, these dampen the prospects of economic growth (Khan, 2001; Kali, 2020b). Empirical studies demonstrate that there is a positive relationship between GDP growth and gender wage inequality (Seguino, 2000). Income inequality significantly slows down economic growth and prospects of poverty reduction (Sen, 1983; Seguino, 2000).

\section{Findings and Discussions}

\subsection{Lesotho's Economy and Causes and Solutions to Poverty}

Lesotho is one of the smallest and poor countries of the world. Its population is estimated at 2,233,339 million with 85\% literacy rate and an achievement of gender parity in many aspects of life (World Economic Forum, 2019, Centers for Disease Control and Prevention, 2019; World Population Review, 2020). The life expectancy in the country is estimated at 56 for females and 52 for males (Centers for Disease Control and Prevention, 2019). The infant mortality rate is around 50.5 as per 1000 live births and deaths and under the age of five is at 71.2 per 1000 live births (Worldometer, 2020). The estimated population of the cities is as follows: Maseru has 118,355 inhabitants, Mafeteng has 57, 056, Leribe has 47,675, Maputsoe has 32,117, Qacha's Nek has 35,573, Quthing has 24,130, and Butha-Buthe has 16,330 (Wolrdometer, 2020). At least $80 \%$ of the population lives in rural areas. At least two-thirds of the country is sparsely inhabited and a large portion of the country is mountainous with deep valleys and scattered villages (Wason \& Hall, 2004). Lesotho is completely landlocked by South Africa such that it cannot have access to the sea without going through its neighbour.

The country possesses a few natural resources. It has water, diamonds, sandstone, and wool and mohair. The country has constructed big dams that make it possible to supply water to Gauteng, a province of South Africa (Rousselot, 2015). Some of the big dams in the country are Katse Dam (completed in 1997), and Mohale Dam which was completed in 2002 (Rousselot, 2015). Polihali Dam is still under construction and has already caused the displacement of at least 8000 people in Mokhotlong but the Amnesty International is demanding the authorities to compensate the victims (Amnesty International, 2020). The Lesotho Highlands Development Project water sales report showed that the country received a sum of M936million in royalties in 2018 for a sale of 779 million cubic meters of water, M903million in royalties for the sale of 779 million cubic of water in 2017, and M837 million from the sale of the same quantity of water in 2016 (Public Eye, 2019). However, there are concerns that the water levels are dropping rapidly. In 2019, Katse Dam was at least $18.21 \%$ full and Mohale Dam was at least $32.47 \%$ full meanwhile Muela hydropower station generates only a small portion of what the country consumes (Public Eye, 2019). Besides the dropping 
levels of water, some citizens are worried that South Africa is draining all the water from Lesotho and the water policy needs to be reviewed (Public Eye, 2019). Others believe that the benefits ripped by the country from the sale of diamonds are not trickling down the people (Wilson, et al., 2008).

The country's diamond also contributes to economic growth and poverty reduction. The country's major mines are Letšeng, Liqhobong, Kao, Kolo, and Mothae and the government owns at least 30\% share from the mines (Newman, 2015). For instance, Gem Diamond Ltd, a foreign company, owned $70 \%$ of Letšeng mine and the government owns $30 \%$ share (Shor et al., 2015). The Letšeng-la-Terae diamond mine produces some of the largest and highest valued diamonds in the world share (Shor et al., 2015; Newman, 2015). The country also has a long history of migrant mine workers working in the mines in South Africa. The miners contribute to the poverty reduction in the country through their remittances albeit their numbers declined significantly when they got retrenched due to political and policy changes in South Africa (Maloka, 1995; Mensah \& Naidoo, 2011).

Basotho's income comes mainly from the government sector and the textile industry. According to Ayoki (2016), the textile and clothing industry is boosted by the African Growth and Opportunity Act and accounted for at least $60 \%$ of the country's total exports in 2016. The industry has managed to create jobs for more than 40000 Basotho. Notwithstanding, recently, a series of protests clamouring for the increase of minimum wage and a salary of M2000 for factory workers have threatened this industry (The Post, 2018). The problem is compounded by the coronavirus pandemic that caused lockdowns and job losses (Molupe, 2020). These problems aggravated poverty in Lesotho.

According to Mokhothu (2004), Basotho view poverty as constituted or defined by the following:

- Lack of food and clothing

- Unemployment of lack of money

- Lack of livestock and agricultural assets

- Illness, poor metal and physical health

- Having no descent or secure shelter

- Lack of adequate water

The country has a lot of challenges and impediments thwarting it from fighting poverty. According to Societe Generale (2020), in 2019, Lesotho was overburdened with a deficit amounting to $8.3 \%$ of its GDP. The country's agriculture sector accounts for only $5.3 \%$ of GDP and the most produced crops are corn, sorghum, wheat, barley, pulses, and livestock production. The revenue generated through the sales of water accounts for at least $10 \%$ of GDP. These developments do not afford the country the help it needs to reduce poverty. This is made evident by the unemployment rate that amounted to $23.4 \%$ in 2019 and has been fluctuating around 20\% for many years (Shale, 2013; Damane \& Sekantsi, 2018). No wonder why the country is rated $164^{\text {th }}$ in the world in terms of human development (Societe Genrale, 2020).

According to Kali and Fanso (2020), One of the factors responsible for poverty in Lesotho is the adoption of Structural Adjustment Programmes (SAPs). The SAPs are an initiative of the International Monetary Fund introduced in the 1980s and 1990s (Kaiser, 2018). The policy inspired a very disproportionate cut on social spending and the state's expenditure on infrastructure was reduced. These interventions aggravated the misery, suffering and poverty of Basotho. The health sector deteriorated although now the government attempted to reverse the effects of poverty by providing a relatively free universal primary healthcare driven by Sustainable Development Goals (SDGs).

In addition to the SAPs, Basotho believe that there are other numerous causes of poverty in the country. They believe that poverty in Lesotho is caused and aggravated by: 
- Loss of employment

- Low income of family head and members of the family

- The largeness of family size

- Lack of access to farmland

- Neglect but the government

- Poor economic conditions (Omole, 2003)

According to Omole (2003), at least $66.7 \%$ of Basotho believe that the government has neglected its responsibility hence the prevalence of poverty. Similarly, 55.2\% are convinced that poverty results from poor access and control of the land. At least $42 \%$ of Basotho associate poverty with high rates of unemployment in the country. The response of the $66.7 \%$ of Basotho that puts the blame on the government cannot be overemphasized. It reveals the lack of commitment and will on the part of the government to create jobs and reduce poverty.

Other studies show that poverty in Lesotho is perpetuated by the interplay between unemployment and lack of economic production. Wilson et al., (2008) found that there is low production in the country and the manufacturing sector is not well developed. This affects the country's ability to create jobs. Apart from that, the poor are not able to send their children to high schools. This is because the government introduced free primary school since 2001 and provides loans for university student but at the secondary and high schools the parents are left bound to pay for their children and many cannot afford the cost thereof. Mwabu et al., (2016) established that poverty in Lesotho is mostly concentrated among households that are headed by widows, uneducated or individuals in subsistence agriculture.

To combat poverty, the government of Lesotho adopted a lot of international policies. The country embraced the Millennium Development Goals (MDGs) with the aim of fighting poverty (Wilson et al., 2008). MDGs were designed by the United Nations (UN) and adopted by countries in September 2000. The goals range from reducing extreme poverty by half to halting the spread of HIV/AIDS that is pervasive in Lesotho by the target date of 2015 (United Nations Development Programme, 2018; Kali, 2018). The goals show an attempt to galvanize unprecedented efforts to fulfil the needs of the world's poorest. The UN worked in tandem with African governments and civil society to build momentum generated by the MDGs so as to end poverty by 2015 (United Nations Development Programmes, 2018). The MDGs sought to do the following:

- Eradicate extreme poverty and hunger

- Achieve universal primary education

- Promote gender equality and empower women

- Reduce child mortality

- Improve maternal health

- Combat HIV/AIDs, malaria, and other diseases

- Ensure environmental sustainability (United Nations Development Programmes, 2018).

At the end of 2015, billions of people were lifted out of poverty although the MDGs were not a complete success, especially in Lesotho and other Sub-Saharan countries, (United Nations Development Programmes, 2018). The major failure of the MDGs is that its benefits were not shared equally across the globe. For instance, while Northern Africa reduced poverty by $1.2 \%$, Sub-Saharan Africa lagged behind. In fact, it failed to meet the goal of reducing extreme poverty and was $12.5 \%$ away from meeting the goal (Gibbs, 2015). The problems that still persist after the end of MDGs include poverty, gender inequality, and pollution from the emission of carbon dioxide (Gibbs, 2015). Fehling et al., (2013) forewarned of the unfolding failures of MDGs as the world population continued to suffer from hunger, particularly in 
countries like Lesotho. The MDGs are said to have failed because they were overambitious and unrealistic (Fehling, et al., 2013). They ignored limited local governance capacities and lacked a special focus on the poorest of the poor (Fehling et al., 2013). Nevertheless, their failure did not generate deep pessimism since the SDGs and other strategies were designed thereafter and Lesotho adopted them to fight poverty.

Lesotho is committed to the implementation of the SDGs and Agenda 2030 as well as Agenda 2063 to fight poverty. The government's commitment is orchestrated by the National Strategic Development Plan II 2018/19-2022/23 (GoL, 2019). A recent report showing the progress of the SDGs and Agenda 2063 states that the country is trying to reduce poverty and hunger, create jobs, reduce inequalities, offer improved universal healthcare, and education services (GoL, 2019).

In 2015, all the UN Member States adopted SDGs as a universal call to action targeted at poverty reduction and ensuring that everyone enjoys peace and prosperity by 2030 (United Nations Development Programmes, 2018). With the SDGs, the government of Lesotho strives to bring the country to zero poverty by ending hunger and disease. The objectives enshrined by the SDGs are as follows:

- To alleviate poverty in all its forms in every continent

- To put an end to hunger, achieve food security, and improved nutrition

- To encourage sustainable agriculture

- To ensure healthy lives and promote the well-being of individuals

- To end gender inequality and empower both women and girls

- To ensure accessibility and continuous management of sanitation and water

- To promote durability, inclusive economic development, and productive employment as well as decent work for everyone

- To build robust infrastructure, stimulate inclusive and sustainable industrialization, and encourage innovation

- To achieve equality among countries

- To improve the inclusiveness, safety, resilience, and sustainability of cities and human settlements

- To guarantee durable production and consumption patterns

- To take swift action to fight climate change and its impacts

- To conserve and sustainably make use of the seas, oceans, and marine resources for sustainable development

- To preserve, restore and encourage sustainable use of terrestrial ecosystems, management of forests, combatting of desertification, halting and reversing of land degradation, and halting of biodiversity loss

- To foster peaceful and inclusive countries so as to attain sustainable development, improve access to justice for all, and construct effective, inclusive and accountable institutions at all levels

- To strengthen the mechanism of execution and rejuvenate the international partnership for sustainable development (United Nations Development Programmes, 2018).

Since Lesotho started embarking on SDGs in 2015, it has not been able to reach the set target of 5\% annual growth (GoL, 2019). Since 2013 up to 2018, its annual GDP growth records managed to rise by $1.9 \%$ whereas from $2013-2015$ it hit $2.2 \%$ (GoL, 2019). The unemployment increased from $25.8 \%$ in 2014/15 to $32.8 \%$ in 2015/6 and in 2020 the coronavirus compounded to that situation (GoL, 2019). Although school enrolment and literacy rate are high among young females more than males in Lesotho, the unemployment rate is around $34 \%$ among females while it is estimated at $29 \%$ for males and this makes women's empowerment and 
inequality dubious (Kali, 2018; GoL, 2019). These developments exposed the inability of the government of Lesotho to create jobs. Such a failure on the side of the government complicates the prospects of ending hunger, improving food security, and achieving equality with countries like South Africa.

In many aspects of life, Lesotho is doing poorly in the implementation of SDGs that help it to reduce poverty. In essence, the country is reversing the gains made in previous years before the adoption of the SDGs and Agenda 2063. For instance, according to the World Economic Forum (2019), with regard to political empowerment, Lesotho ranked 41 in 2006 but declined to 102 in 2020. Equally, in relation to economic participation and opportunity, the country ranked 61 in 2006 but was demoted to number 84 in 2020. These changes undermined the progress the country was making and compelled it to be demoted from number 43 recorded in 2006 to number 88 in 2020 under the Global Gender Gap index.

However, the government of Lesotho has managed to reduce absolute poverty. From 2003 to 2018 , national poverty declined from $56.6 \%$ to $49.7 \%$ while extreme poverty declined from $34.1 \%$ to $24.1 \%$ (GoL, 2019). The government is almost succeeding in achieving universal primary education since the primary school enrolment recorded $87 \%$ in 2017 . At the universities, there are about $60 \%$ females and 39.5\% males (GoL, 2019) and this shows that women's empowerment is successful whatever the reasons behind it (Kali, 2018). The government managed to close the gender gap and achieve gender equality. According to the World Economic Forum (2019), the country has already achieved gender parity in education. In terms of income as well, Lesotho has closed $50 \%$ of the gap. In terms of educational attainment and health survival, the country ranked number 01 in the world since 2006 to the present.

In addition, Lesotho has also developed a robust social protection system that covers child protection, women's empowerment, child grants programme, old age pension and programme for people living with disabilities and migrants (GoL, 2019). According to Westphal (2016), the country provides all citizens aged over 70 years of age with a monthly pension to lift them out of poverty. The scheme covered at least 83000 persons which makes around $4.5 \%$ of the population. By this means, the government endeavours to reduce the number of people living under $\$ 1.90$ per day.

\subsection{Prospects of Poverty Reduction in Lesotho}

It is worth noting that the SDGs stretch from 2015 to 2030. This means that the progress made by the government of Lesotho is commendable since there is still a vast room for improvements. Added to that is the opportunity presented by the country's adoption of the African Union Agenda 2063. The Agenda 2063's objectives coincide with that of the SDGs hence the progress already made by Lesotho covers the two poverty reduction strategies. In addition, the Agenda 2063 expands the room for improvement so that Lesotho can correct the mistakes encountered in the achievement of the MDGs and SDGs.

The progress made by Lesotho on SDGs is consistent with the African Union Agenda 2063 whose purpose is to speed up the implementation of past and present continent initiatives to stimulate growth and sustainable development (Prady and Sy, 2019). Agenda 2063 is the continent's blueprint and master plan for ending poverty. It represents a strategic framework designed to deliver inclusive and sustainable development issues (African Union Commission, 2015). The Agenda 2063 stretches from 2013 to 2063 and encapsulates Africa's aspirations (African Union Commission, 2015). Agenda 2063 is also embraced by Lesotho and includes the following aspirations:

A prosperous continent based on shared growth and sustainable development

- A politically integrated and united continent which relies on the principles of PanAfricanism and the idea of Africa's Renaissance 
- Africa of democracy, good governance, respect for human rights, the rule of law and justice

- A secure and peaceful Africa

- An Africa with a common heritage, a vigorous cultural identity, and common values and ethics

- A continent whose development is stimulated by the people, and relies on their potential, especially the youth and women, and cares for children

- Africa as a united, resilient, and influential partner and global player (African Union Commission, 2015).

The commitment of Lesotho to the Agenda 2063 is already visible and the country can benefit a lot from the unfolding development in future. In line with the Agenda 2063, the Africa Union created the Pan African University with at least five campuses based in the following countries: Kenya, Algeria, Nigeria, Cameroon and South Africa (African Union Commission, 2019). Lesotho is already benefitting from this development as some of its citizens, including the author of this paper, are already benefiting from the fully-funded scholarship offered by the African Union.

In addition, the Lesotho can capitalize on SDGs by learning from the past mistakes committed during the implementation of the MDGs that preceded them. The country has the opportunity to coordinate and collaborate the SDGs with Agenda 2063 developments and merge targets to avoid duplication of efforts. The SDGs can get wider support since they place emphasis on the scientific community which its predecessor ignored (Jaiyesimi, 2016). When addressing renewable energy, climate change and water management, the Agenda 2063 should promote peace while SDGs work on sustainable development as the goals and targets demands. The country has the opportunity to adhere to the goals of the two strategies and compensate the 8000 citizens displaced during the construction of Polihali Dam (Amnesty International, 2020). In addition, the two policies present an opportunity for Lesotho to prevent future political instability and conflict like the one that led to the intervention of the Southern African Development Community in 1998 (Kali, 2019), so that it can focus on peaceful development, poverty reduction and expand its Muela hydroelectric power station.

Apart from that, the implementation of SDGs by the continental and regional countries show that governments are succeeding to reduce poverty. Sub-Saharan African countries were always regarded as the poorest regions of the world with at least half of the extreme poor and $82 \%$ of them living in rural areas (World Bank, 2019; World Bank, 1996; Roser and OrtizOspina, 2019). However, some reports demonstrate that for the first time since the continent embarked on the SDGs, poverty is declining among 367 people per day (Hamel et al., 2019). This means that by the end of 2020, poverty will decline among 1 million people in Africa (Hamel et al., 2019). These promising reports like SDGs combine with the aim of the Agenda 2063 to show that Lesotho is likely to reduce its poverty.

\section{Conclusion}

The study has highlighted the causes of poverty in Lesotho. It has explained the dimensions of poverty affecting the country and confined itself to the causes that are not natural. The findings of the study reveal that the country embraced some detrimental policies like the SAPs without prior assessment of their repercussions. Poverty in the country is caused mainly by the government's negligence. These disregards of the welfare of citizens have resulted in high unemployment and dire poverty. Besides that, the government has reversed the gains made in 2006 so that the country's rankings in terms of economic participation and empowerment dropped from 61 to 84 as well as political empowerment have dropped from 41 to 102 in 2020 as indicated by the Global Gender Gap index. 
However, the government has maintained some of the gains made since 2006 . The country has maintained its number one rank in terms of educational attainment and health survival in the world. The government of Lesotho offers free universal primary education which has seen at least $87 \%$ enrolment. Moreover, the government provides loans to universities to students and has managed to attain $60 \%$ enrolment of females and $39.5 \%$ among males at the universities. Although this does not translate into equal economic opportunities since females account for $34 \%$ of the unemployed citizens while males only account for $29 \%$.

In addition, Lesotho has created a robust social protection system to fight poverty. Its programme covers child protection which creates a protective environment for children. It also covers women's empowerment strategies that helped it to close the gender gap in education. The government also offers child grants and old age pension and developed programmes for people living with disabilities and migrants. In a nutshell, given the long journey remaining towards the end of SDGs and Agenda 2063 and the strides made by the country, the paper concludes that Lesotho is in the right direction to reducing poverty especially because there is still a vast room for improvements.

\section{Acknowledgements}

The author would like to extent his appreciation to Thuso Mosabala (a Masters student) and Paul Onyalo (a PhD candidate), both from the Pan African University for their invaluable comments to this paper.

\section{References}

Acemoglu, D., \& Robinson. (2001). Why is Africa Poor? Economic History of Developing Regions, 25(1), 21-50. https://doi.org/10.1080/20780389.2010.505010

African Union Commission. (2015). Agenda 2063: The Africa We Want. https://www.un.org/en/africa/osaa/pdf/au/agenda2063.pdf

African Union Commission. (2019). Pan African University (PAU). AU Education. https://www.edu-au.org/agencies/pau

Ajakaiye, D. O., \& Adeyeye, V. A. (2001). Concepts, measurement and causes of poverty. CBN Economic and Financial Review, 39(4).

Amnesty International. (2020, February 6). Lesotho: 8000 people at risk of displacement in Lesotho due water deal with South Africa. https://www.amnesty.org/en/latest/news/2020/02/lesotho-polihali-dam-construction-putsnearly-8000-people-at-risk-of-displacement/

Annamalai, T. R., Devkar, G., Mahalingam, A., Benjamin, S., Rajan, S. C., \& Deep, A. (2016). What is the evidence on top-down and bottom-up approaches in improving access to water, sanitation and electricity services in low-income or informal settlements? EPPI-Centre, Social Science Research Unit, UCL Institute of Education, University College London. https://eppi.ioe.ac.uk/CMS/Portals/0/PDF\%20reviews\%20and\%20summaries/SANITATI ON\%202016\%20Annamalai.pdf

Ayoki, M. (2016). The textile and clothing industry in Lesotho in the wake of the multi-fibre agreement phase-out (88112). Institute of Policy Research and Analysis.

Baylis, J., Smith, S., \& Owens, P. (2011). The globalization of world politics: An introduction to international relations. Oxford University Press.

Beard, V. A. (1999). The Capacity of Community-Based Planning to Reduce Urban Poverty: A Case Study of Gondolayu Lor in Yogyakarta [Unpublished doctoral dissertation]. University of British Columbia. 
Bratton, M., \& Van de Walle, N. (1994). Neopatrimonial regimes and political transitions in Africa. World Politics, 46(4), 453-489. https://doi.org/10.2307/2950715

Centers for Disease Control and Prevention. (2019, July 22). CDC global health - Lesotho. https://www.cdc.gov/globalhealth/countries/lesotho/default.htm

Chambers, R. (1995). Poverty and livelihoods: Whose reality counts? Environment and Urbanization, 7(1), 173-204. https://doi.org/10.1177/095624789500700106

Damane, M., \& Sekantsi, L. (2018). The sources of unemployment in Lesotho. Modern Economy, 9(5), 937-965.

Damane, M., \& Sekantsi, L. P. (2018). The sources of unemployment in Lesotho. Modern Economy, 09(05), 937-965. https://doi.org/10.4236/me.2018.95060

Deni, A., \& Lippit, V. (2009). Poverty, from Orthodox to Heterodox Approaches: a Methodological Comparison Survey. University of California.

Fehling, M., Nelson, B. D., \& Venkatapuram, S. (2013). Limitations of the millennium development goals: A literature review. Global Public Health, 8(10), 1109-1122. https://doi.org/10.1080/17441692.2013.845676

Gibbs, G. (2020, June 24). MDG failures: Shortcomings of the millennium development goals. The Borgen Project. https://borgenproject.org/mdgfailures/\#: :text=One\%20of\%20the\%20major\%20MDG,countries\%20concerning\%20the $\% 20$ same $\% 20$ MDGs.\&text=Southeastern $\% 20$ Asia $\% 20$ exceeded $\% 20$ the $\% 20$ goal $\% 20$ for $\%$ 20extreme\%20poverty\%20reduction $\% 20$ by $\% 2016 \% 20$ percent

Global Economy.com. (2020). Lesotho External debt - data, chart| TheGlobalEconomy.com. https://www.theglobaleconomy.com/Lesotho/External_debt/

GoL [Government of Lesotho]. (2019). The Kingdom of Lesotho Voluntary National Review on the Implementation of the Agenda 2063 Report 2019. https://sustainabledevelopment.un.org/content/documents/23777Lesotho_VNR_Report Latest_28_June_2019.pdf

Gupta, S. (1984). Conceptualizing poverty. Sociological Bulletin, 33(1/2), 63-74.

Hamel, K., Tong, B., \& Hofer, M. (2019, March 28). Poverty in Africa is now falling-but not fast enough. Brookings. https://www.brookings.edu/blog/futuredevelopment/2019/03/28/poverty-in-africa-is-now-falling-but-not-fast-enough/

Hope, K., \& Chikulo, B. (1999). Corruption and development in Africa: Lessons from country case studies. Springer.

Jaiyesimi, R. (2016). The challenge of implementing the sustainable development goals in Africa: The way forward. African Journal of Reproductive Health, 20(3), 13-18. https://doi.org/10.29063/ajrh2016/v20i3.1

Kaiser, J. (2020, August 7). Shortcomings and weaknesses of the structural-adjustment measures of recent decades. D+C. https://www.dandc.eu/en/article/shortcomings-andweaknesses-structural-adjustment-measures-recent-decades

Kali, M. (2020a). Characteristics of Bureaucracy: Examining the Relations between Bureaucrats and Politicians in Lesotho. European Journal of Behavioral Sciences, 19(2), 20-33.

Kali, M. (2020b). Challenges and Prospects of decentralization in Lesotho. International Journal of Humanities, Art and Social Studies, 5(2), 11-20. 
Kali, M., \& Muchie, M. (2020). Poverty in Africa: Root causes and solutions. Journal of Economic and Social Research, 19(2), 100-110.

Kali, M. (2018). Representation of Women. A Case Study of the Parliament of Lesotho [Master's thesis]. https://books.google.cm/books/about/Representation_of_Women_A_Case_Study_of.html? id=JYvZzQEACAAJ\&redir_esc=y

Kali, M. (2018). Women empowerment in Lesotho: Reality and/or myth? International Journal of Scientific Research and Management, 6(03). https://doi.org/10.18535/ijsrm/v6i3.sh06

Kali, M. (2019). Democratic Reversals: Examining the Role of the Armed Forces and Southern African Development Community in Lesotho. International Journal of Research and Innovation in Social Science, $3(11), \quad$ 140-145. https://www.rsisinternational.org/journals/ijriss/Digital-Library/volume-3-issue-11/140145.pdf

Khan, M. H. (2001). Rural poverty in developing countries: Implications for public policy. International Monetary Fund.

Laderchi, C. R., Saith, R., \& Stewart, F. (2003). Does it Matter that we do not Agree on the Definition of Poverty? A Comparison of Four Approaches. Oxford Development Studies, 31(3), 243-274. https://doi.org/10.1080/1360081032000111698

Maloka, E. T. (1995). Basotho and the mines: towards a history of labour migrancy, c.18901940 [Unpublished master's thesis]. University of Cape Town.

May, J., Roberts, B., Moqasa, G., \& Woolaed, I. (2002). Poverty and Inequality in Lesotho (36).

CSDS. https://www.researchgate.net/publication/251636742_Poverty_and_Inequality_in_Lesotho

Mensah, S. N., \& Naidoo, V. (2011). Migration shocks: Integrating Lesotho's retrenched migrant miners. International Migration Review, 45(4), 1017-1042. https://doi.org/10.1111/j.1747-7379.2011.00875.x

Mokhothu, M. M. (2004, April). Causes of Poverty [Paper presentation]. 25TH AAPAM Annual roundtable conference, Kairaba Beach Hotel, Banjul. https://pdfs.semanticscholar.org/fd2f/f8f235dce252243629b9ec89225e16e6bddf.pdf?_ga= 2.105146880.284988339.1602798047-891791242.1602798047

Molupe, G. (2020, February 18). Returning Chinese cause panic in Lesotho. City Press. https://www.news24.com/citypress/news/returning-chinese-cause-panic-in-lesotho20200215

Mwabu, G., Kimani, M., Ng'ang'a, M., Maara, N., Kamori, P. T., Machio, P., Githuku, S., \& Mutuku, S. (2016). Determinants of poverty in Lesotho: a household level. https://www.semanticscholar.org/paper/DETERMINANTS-OF-POVERTY-IN-

LESOTHO\%3A-A-HOUSEHOLD-MwabuKimani/9c5431a3e6c3274e15d8df1f69626f87ef07549f

Naidoo, P. (2020, September 2). Africa may have $90 \%$ of the world's poor in next 10 years, World Bank says. Bloomberg.com. https://www.bloomberg.com/news/articles/2019-1009/africa-may-have-90-of-the-world-s-poor-by-2030-world-bank-says

Newman, H. (2015). The Mineral Industries of Lesotho and Swaziland. U.S. Department of the Interior; U.S. Geological Survey. https://s3-us-west-2.amazonaws.com/prdwret/assets/palladium/production/mineral-pubs/country/2012/myb3-2012-lt-wz.pdf 
News24. (2017). Africa 'is not poor, we are stealing its wealth. News24, pp. https://www.news24.com/Africa/News/africa-is-not-poor-we-are-stealing-its-wealth20170526.

Omole, D. A. (2003). Poverty in Lesotho: a case study and policy option. Lesotho Social Science Review, 9, 1-13.

Patel, N. (2018, November 21). Figure of the week: Understanding poverty in Africa. Brookings. https://www.brookings.edu/blog/africa-in-focus/2018/11/21/figure-of-theweek-understanding-poverty-in-africal

Prady, D., \& Sy, M. (2019, December 6). The spending challenge for reaching the SDGs in sub-Saharan Africa: Lessons learned from Benin and Rwanda. IMF. https://www.imf.org/en/Publications/WP/Issues/2019/12/06/The-Spending-Challenge-forReaching-the-SDGs-in-Sub-Saharan-Africa-Lessons-Learned-from-48753

Public Eye. (2019, September 17). Explainer: how much money Lesotho earns from sale of water to sa. Public Eye. https://www.nwlesotho.co.ls/explainer-how-much-money-lesothoearns-from-sale-of-water-to-

sa/\#: :text=The\%20LHDA\%20water\%20sales\%20report,about\%20M903\%20million\%20 in\%20royalties

Ravillion, M. (1992). Poverty comparisons: A guide to concepts and methods (88). The World Bank. https://agris.fao.org/agris-search/search.do?recordID=US2012417541

Roser, M., \& Ortiz-Ospina, E. (2019). Global extreme poverty. Our World in Data. https://ourworldindata.org/extreme-poverty

Rousselot, Y. (2015). Upstream flows of water: From the Lesotho Highlands to metropolitan South Africa. Revue de géographie alpine, (103-3). https://doi.org/10.4000/rga.3023

Seguino, S. (2000). Gender inequality and economic growth: A cross-country analysis. World Development, 28(7), 1211-1230. https://doi.org/10.1016/s0305-750x(00)00018-8

Sen, A. (1983). Poor, relatively speaking *. Oxford Economic Papers, 35(2), 153-169. https://doi.org/10.1093/oxfordjournals.oep.a041587

Senadza, B., Korsi, F., \& Peter, Q. (n.d.). The effect of external debt on economic growth in Sub-Saharan Africa. International Journal of Business and Economic Sciences Applied Research, 11(1), 61-69. http://dx.doi.org/10.25103/ijbesar.111.07

Shale, M. (2013). Unemployment biggest problem for basotho, who also endorse illegal migration to get jobs (119). Afrobarometer. https://afrobarometer.org/sites/default/files/publications/Briefing\%20paper/afrobriefno119 .pdf

Shor, R., Weldon, R., Janse, A., Breeding, C. M., \& Shirey, S. B. (2015). Letseng's unique diamond proposition. Gems \& Gemology, 280-299. https://doi.org/10.5741/gems.51.3.280

Societe Generale. (2020, October). Country risk of Lesotho: Economy. Import-Export Solutions : démarrez votre développement international en toute sérénité. https://importexport.societegenerale.fr/en/country/lesotho/economy-country-risk

South Africa tries to ease internal Lesotho tension after PM deploys army. (2020, April 20). Reuters. https://www.reuters.com/article/us-lesotho-politics/south-africa-tries-to-easeinternal-lesotho-tension-after-pm-deploys-army-idUSKBN2221QP

Stapleford. (1919). Causes of Poverty. The Public Health Journal, 10(4), 157- 161. 
The Post. (2018, August 24). Blow for factory workers. The Post. https://www.thepost.co.ls/news/blow-for-factory-workers/

Townsend, P. (1962). The meaning of poverty. The British Journal of Sociology, 13(3), 210227.

Townsend, P. (1993). International analysis poverty. Routledge.

Ueckermann, E., \& Blignaut, J. (2005). The attitude and vulnerability of people as determinants of poverty: The case of Lesotho. South African Journal of Economic and Management Sciences, 8(4), 465-478. https://doi.org/10.4102/sajems.v8i4.1176

United Nations Development Programme. (2018, April 26). From MDGs to SDGs. Sustainable Development Goals Fund. https://www.sdgfund.org/mdgs-sdgs

United Nations Development Programme. (2020). Human Development Reports. http://hdr.undp.org/en/countries/profiles/LSO

Ventura, L. (2020, July 22). Poorest Countries in the World 2020| Global Finance Magazine. https://www.gfmag.com/global-data/economic-data/the-poorest-countries-in-the-world

Wason, D., \& Hall, D. (2004). Poverty in Lesotho: 1993 to 2002: An Overview of Household Economic Status and Government Policy (40). https://assets.publishing.service.gov.uk/media/57a08cd0ed915d622c0015c7/40Wason_Hal 1.pdf

Westphal, T. (2019). Universal Old Age Pension. International Labour Office. https://www.social-

protection.org/gimi/gess/RessourcePDF.action?ressource.ressourceId=53518\#: :text=All $\% 20$ citizens $\% 20$ of $\% 20$ Lesotho\%20over,per\%20cent $\% 20$ of $\% 20$ the $\% 20$ population)

Wilson, S. M., Mapetla, M. M., \& Power-Drutis, T. (2008). Global initiatives and local leadership: the role of leadership in eradicating poverty in Lesotho Africa. Journal of Sustainable Development in Africa, 10(2), 51-89.

Wong, S. Y. (2012). Understanding poverty: Comparing basic needs approach and capability approach. SSRN Electronic Journal. https://doi.org/10.2139/ssrn.2066179

World Bank. (1996). Taking Action for Poverty Alleviation in Sub-Saharan Africa (Washington D.C). Report of an African Task Force, May 1.

World Bank. (2019). Accelerating poverty reduction in Africa: In five charts. https://www.worldbank.org/en/region/afr/publication/accelerating-poverty-reduction-inafrica-in-five-charts

World Economic Forum. (2019). Global Gender Gap Report 2020. https://www3.weforum.org/docs/WEF_GGGR_2020.pdf

World Population Review. (2020, July 1). Lesotho population 2020 (Demographics, maps, graphs). $2020 \quad$ World Population Country. https://worldpopulationreview.com/countries/lesotho-population 